\title{
GAMBARAN DUKUNGAN SUAMI DI DESA SIMPEN KIDUL KECAMATAN LIMBANGAN KABUPATEN GARUT TAHUN 2012.
}

Oleh :

Purwati, AM. Keb, SKM,MARS

\section{A. Abstrak}

Pada tahun 2012 di Desa Simpen Kidul, jumlah ibu hamil sebanyak 87 orang, masih ada ibu yang bersalin di paraji sebanyak 12 orang, dan yang bersalin di bidan sebanyak 31 orang, dengan tenaga kesehatan 1 orang bidan dan 1 orang mantri, ternyata persalinan yang di tolong oleh nakes masih rendah. Salah satu peran serta suami selama kehamilan dalam rangkamerencanakan persiapan persalinan adalah suami dapat memastikan persalinanistrinya di tolong oleh tenaga kesehatan terlatih dan aman,bersalin di fasilitas kesehatan yang memadai. Tujuan penelitian adalah untuk mengetahui gambaran dukungan suami di Desa Simpen Kidul Kecamatan Limbangan Kabupaten Garut Tahun 2012.

Jenis penelitian yang digunakan adalah kuantitatif dengan menggunakan metoda deskriptif yaitu menggambarkan dukungan suami dengan rencana persiapan yang ibu lakukan dalam persalinannya.. Populasi dalam penelitian ini adalah seluruh ibu hamil yang berada di Desa Simpen Kidul Kecamatan Limbangan Kabupaten Garut periode Mei sampai Juni 2012 yaitu 87 orang. Instrument dalam penelitian berupa format kuesioner yang ditujukan kepada ibu hamil untuk menggambarkan dukungan suami dengan persiapan persalinan Sebanyak 20 pertanyaan. Analisis univariat dilakukan untuk mendeskripsikan dua variabel yang diteliti.

Berdasarkan hasil penelitian didapatkan bahwa dukungan suami dalam persiapan persalinan pada ibu hamil di Desa Simpen Kidul Kecamatan Limbangan Kabupaten Garut Tahun 2012 ada pada kategori mendukung. Serta persiapan persalinan ibu hamil di Desa Simpen Kidup Kecamatan Limbangan Kabupaten Garut tahun 2012 ada pada kategori kurang.

Kesimpulan penelitian didapatkan bahwa dukungan suami dalam persiapan persalinan pada ibu hamil di Desa Simpen Kidul Kecamatan Limbangan Kabupaten Garut Tahun 2012 ada pada kategori mendukung. Serta persiapan persalinan ibu hamil di Desa Simpen Kidup Kecamatan Limbangan Kabupaten Garut tahun 2012 ada pada kategori kurang. Sehingga rekomendaasi saran yang diberikan adalah Suami harus memberikan dukungan dalam persiapan persalinan kepada istrinya dan membantu istri mempersiapkan persalinan serta pemberi pelayanan lebih meningkatkan fasilitas pelayanan serta media informasi khususnya persiapan persalinan di fasilitas kesehatan agar bersalin sehat, aman dan nyaman.

\section{Kata Kunci : Dukungan suami, Persiapan persalinan}




\section{B. Latar Belakang}

Berdasarkan data World Health Organization (WHO) salah satupenyebab faktor kematian ibu $60 \%-80 \%$ adalah pendarahaan pada saat melahirkan, persalinan macet, sepsis, tekanan darah tinggi pada saat kehamilan dan terjadinya komplikasi kehamilan. Kondisi kematian ibu secara keseluruhan diperberat oleh "4 terlambat" dan "4 terlalu" yaitu terlambat dalam mengenali resiko atau bahaya yang terjadi pada ibu, terlambat mengambil keputusan untuk merujuk ke fasilitas kesehatan yang Peran serta keluarga dalam mempertahankan dan meningkatkan kesehatan keluarga pada dasarnya adalah upaya untuk menurunkan angka kematian. Salah satu wujud peran serta keluarga dapat diwujudkan dalam partisipasi saat pemeriksan selama hamil (Antenatal Care) adalah suatu program yang terencana berupa observasi, edukasi dan penanganan medik pada ibu hamil, untuk memperoleh suatu proses kehamilan dan persalinan yang aman dan memuaskan pada intinya bertujuan untuk menekan angka kematian ibu melahirkan dan menurunkan angka kematian bayi. Antenatal Care penting dilakukan untuk menyiapkan kondisi ibu selama kehamilan dan mendeteksi adanya penyulit selama kehamilan, hal ini di tunjang dengan adanya tempat pelayanan kesehatan yang telah disediakan baik oleh pemerintah maupun swasta dan tenaga kesehatan terlatih dan kompeten yang siap memberikan pelayanan kepada ibu. (Mufdlilah, 2009).

Salah satu peran serta suami selama kehamilan dalam rangka merencanakan persiapan persalinan adalah suami dapat memastikan persalinanistrinya di tolong oleh tenaga kesehatan terlatih dan aman, bersalin difasilitas kesehatan yang memadai, untuk itu suami perlu memberikan dukungan kepada istrinya untuk mempersiapkan persalinan supaya persalinan dapat terencana dengan baik.

Pada tahun 2012 di Desa Simpen Kidul, jumlah ibu hamil sebanyak 87orang, masih ada ibu yang bersalin di paraji sebanyak 12 orang, dan yang bersalin di bidan sebanyak 31 orang, dengan tenaga kesehatan 1 orang bidan dan 1 orang mantri, ternyata persalinan yang di tolong oleh nakes masih rendah, disbanding dengan desa dunguswiru yang hampir $100 \%$ ditolong oleh nakes, di tambah dengan jumlah ibu yang bersiko masih banyak. Informasi yang didapatkan dari Bidan Desa setempat bahwa pada umumnya Ibu yang bersalin di paraji adalah ibu yang jarang melakukan pemeriksaan ANC di bidan, sehingga dari awal tidak mempersiapkan persalinannya ditambah dengan kurangnya dukungan suami untuk melakukan pemeriksaan ANC, bentuk dukungan yang bisa diberikan suami kepada istrinya yaitu dengan memotivasi untuk melakukan pemeriksaan, mengantar atau menemani istrinya melakukan pemeriksaan dan mengingatkan jadwal kunjungan yang telah ditetapkan oleh tenaga kesehatan.

Berdasarkan data tersebut dapat diasumsikan bahwa jumlah persalinan oleh nakes akan meningkat dan tidak ada ibu hamil yang beresiko, dengan melakukan persiapan persalinan, disini peneliti ingin menghubungkan jika suami memberikan dukungan apakah ibu akan mempersiapkan persalinannya atau sebaliknya, maka peneliti tertarik untuk melakukan penelitian mengenai "Gambaran dukungan suami dalam persiapan Persalinan pada ibu hamil di Desa Simpen Kidul Kecamatan Limbangan Kabupaten Garut tahun 2012”. Tujuan penelitian adalah untuk mengetahui gambaran dukungan suami di Desa Simpen Kidul Kecamatan Limbangan Kabupaten Garut Tahun 2012. 


\section{Metode}

Jenis penelitian yang digunakan adalah kuantitatif dengan menggunakan metoda deskriptif yaitu menggambarkan dukungan suami dengan rencana persiapan yang ibu lakukan dalam persalinannya.

Populasi dalam penelitian ini adalah seluruh ibu hamil yang berada di Desa Simpen Kidul Kecamatan Limbangan Kabupaten Garut periode Mei sampai Juni 2012 yaitu 87 orang.

Pengambilan sampel dalam penelitian ini menggunakan teknik total sampling yaitu seluruh ibu hamil yang berada di Desa Simpen Kidul Kecamatan Limbangan Kabupaten Garut Tahun 2012.

Instrument dalam penelitian
berupa format kuesioner yang ditujukan kepada ibu hamil untuk menggambarkan dukungan suami dengan persiapan persalinan Sebanyak 20 pertanyaan.

Pengolahan Data

Pengolahan data dalam suatu penelitian merupakan langkah yang sangat penting, karena data tersebut dapat memberikan makna dan memenuhi tujuan penelitian.

$$
\text { Adapun langkah langkah }
$$

\section{Hasil Penelitian}

Karakteristik responden dalam penelitian ini penting untuk menunjang pembahasan, karakteristik dalam penelitian ini meliputi: umur, tingkat pendidikan, dan pekerjaan. Berikut karakteristik responden dapat dilihat pada tabel dibawah ini :

1. Umur Responden

Berdasarkan tabel 5.1. menunjukkan bahwa sebagian besar responden ada pada kategori umur 20-35 tahun yaitu sebanyak 66 orang $(75,9 \%)$, sedangkan sebanyak 9 orang $(10,3 \%)$ ada pada kategori > 35 tahun.

2. Tingkat Pendidikan

Berdasarkan tabel 5.2. menunjukkan bahwa sebagian besar responden ada pengolahan data adalah sebagai berikut:

a. Editing data, yaitu pemeriksaan kuesioner apakah masih ada yang kurang lengkap atau masih ada jawaban yang kurang konsisten, apabila ada 3 jawaban yang kurang konsisten atau pertanyaan yang tidak di isi maka jawaban tersebut dianggap mising.

b. Coding data, yaitu Setelah data di edit dan telah memenuhi kriteria untuk dapat diolah lebih lanjut, lalu data tersebut diberi kode-kode untuk setiap item pertanyaan yang diberikan, yaitu mengubah karakter jawaban kedalam bentuk angka dengan tujuan untuk mempermudah pengolahan data.

c. Entri data, yaitu memasukan data ke dalam komputer.

Analisis Data

Analisis univariat dilakukan untuk mendeskripsikan dua variabel yang diteliti yaitu dukungan suami dalam bentuk dukungan emosional perilaku, dana, dan mendeskripsikan persiapan persalinan. Sebelum dilakukan analisa data peneliti terlebih dahulu menyeleksi kelengkapan hasil kuesioner kemudian dilakukan tabulasi sehingga frekuensi setiap jawaban dapat di periksa.

pada kategori tingkat pendidikan SD yaitu sebanyak 37 orang $(42,5 \%)$, sedangkan sebanyak 4 orang $(4,6 \%)$ ada pada kategori tingkat pendidikan Diploma/Perguruan Tinggi.

3. Pekerjaan Responden

Berdasarkan tabel 5.3. menunjukkan bahwa sebagian besar responden berdasarkan pekerjaan ada pada kategori tidak bekerja yaitu sebanyak 69 orang $(79,3 \%)$, sedangkan sebanyak 4 orang $(4,6 \%)$ ada pada kategori tingkat pegawai swasta.

Hasil penelitian mengenai dukungan suami dan persiapan persalinan pada ibu hamil di Desa Simpen Kidul Kecamatan Limbangan Kabupaten Garut tahun adalah sebagai berikut: 
d. Dukungan Suami

Data hasil penelitian tentang dukungan suami diperoleh dari 87 responden yang melakukan pengisian kuesioner sebanyak 12 pertanyaan dengan hasil ukur sebagai berikut:

e. Mendukung, jika responden menjawab ya $\geq 75 \%$ dari item pertanyaan yang telah disediakan.

f. Kurang mendukung, jika responden menjawab ya $\leq 75 \%$ dar itempertanyaan yang telah disediakan. Berdasarkan tabel 5.4. menunjukkan bahwa sebagian besar responden sebanyak 47 orang $(54,0 \%)$ menyatakan mendukung dalam persiapan persalinan

\section{E. Pembahasan}

1. Dukungan Suami dalam Persiapan Persalinan

Berdasarkan hasil penelitian mengenai dukungan suami dalam persiapan persalinan pada ibu hamil di Desa Simpen Kidul Kecamatan Limbangan Kabupaten Garut Tahun 2012, diperoleh bahwa suami memberikan dukungan dalam persiapan persalinan sebesar 54,5\%, hasil penelitian berdasarkan temuan dilapangan, bila diperinci bentuk dukungan pada umumnya suami memberikan dukungan dalam bentuk persiapan biaya sebanyak 70 orang responden $(85,5 \%)$ sudah menyiapkan biaya untuk persalinan, meskipun sudah ada jaminan persalinan yang sudah ditetapkan pemerintah persiapan biaya tetap diutamakan karena pada saat persalinan nanti biaya sangat diperlukan untuk hal yang tidak terduga, seperti biaya transportasi, membeli obat-obatan yang diperlukan karena tidak ada ditempat pelayanan kesehatan ketika persalinan, dan untuk penunggu pasen jika suatu ketika ibu harus ada dalam perawatan, Hal ini sesuai dengan teori menurut Murya (2008) Persiapan yang paling banyak dipikirkan dan diutamakan adalah mengenai biaya, karena akan pada ibu hamil, sedangkan sisanya sebanyak 40 orang $(46,0 \%)$ tidak mendukung.

Persiapan Persalinan

Data hasil penelitian tentang persiapan persalinan diperoleh dari 87 responden yang melakukan pengisian kuesioner sebanyak 8 pertanyaan dengan hasil ukur sebagai berikut:

Cukup, jika responden mempersiapkan persalinan

Kurang, jika responden mempersiapkan persalinan $\quad 40 \%$ dari itempertanyaan yang telah disediakan.

berpengaruh pada aspek lain seperti persiapan transportasi, donor darah, persiapan perlengkapn dan lain-lain.

Responden menganggap biaya sangat penting dan dibutuhkan pada saat persalinan nanti, banyak cara dilakukan responden dalam mempersiapkan biaya diantaranya ada sebagian responden yang mempersiapkan biaya dengan upaya menabung sesuai dengan kemampuan masing-masing, sehingga berharap meringankan beban pada saat persalinan, kegiatan menabung merupakan hal yang tepat dilakukan oleh responden dengan pertimbangan meskipun sudah ada jaminan persalinan dari pemerintah ditakutkan ada suatu hal yang tidak dapat diprediksi sehingga memerlukan biaya yang besar. Fakta dilapangan menunjukan bahwa masing-masing responden sudah menyiapkan biaya untuk persalinan, adapun sejalan dengan hal tersebut menurut Senduk (2007) mempersiapkan perlengkapan ibu, perlengkapan bayi dan keuangan untuk menyongsong kelahiran bayi sangat penting, salah satunya yaitu dengan cara menabung.

Selain biaya persalinan suami juga memberikan uang untuk membeli perlengkapan ibu dan bayi, menurut 
data yang diperoleh dilapangan sebanyak 64 orang $(73,6 \%)$, bahkan ada sebagian responden yang sudah mengantar istrinya membeli perlengkapan untuk ibu dan bayinya, responden mengaku sangat senang bisa membelikan istrinya peralatan untuk bayinya, ada juga sebagian responden yang hanya memberikan uangnya saja tanpa mengantar untuk membelikan peralatan karena kesibukan yang tidak bisa ditinggalkan dan ada juga yang menyuruh orang tuanya untuk membelikan peralatan, responden mengaku tidak tahu apa yang harus dibeli karena ini kehamilan pertama bagi istrinya jadi belum ada pengalaman sebelumnya, beragam bentuk dukungan diberikan suami dalam menyambut persalinan anaknya hal itu adalah sebagian rasa bahagia yang ditunjukan dari seorang suami karena akan ada anggota keluarga baru dalam kehidupannya.

Pemilihan penolong persalinan oleh tenaga kesehatan sangat penting dipersiapkan ini merupakan salah satu upaya untuk menurunkan angka kematian ibu dan bayi, menurut data yang diperoleh dari hasil penelitian sebanyak 63 orang $(72,4 \%)$ suami sudah merencanakan istrinya untuk bersalin di tenaga kesehatan (bidan). hal ini sesuai dengan hapsari (2008) yang menyatakan bahwa salah satu komitmen untuk mengurangi angka kematian, kesakitan yang berhubungan dengan komplikasi kehamilan, persalinan, dan selama nifas adalah agar ibu hamil, melahirkan dan dalam masa setelah persalinan mempunyai akses terhadap tenaga kesehatan yang terlatih. Penolong persalinan yang direncanakan oleh suami untuk persalinan istrinya sangat beragam disesuaikan dengan pengasilan masing-masing, peneliti menemukan ada responden yang masih memilih paraji sebagai penolong persalinan padahal usia istrinya diatas 35 tahun, responden mengatakan lebih memilih paraji karena alasan biaya, penghasilannya hanya mencukupi makan untuk sehari-hari, memeriksakan kehamilan pun tidak pernah, peneliti yang ditemani kader melakukan pendekatan kepada responden memberikan konseling tentang resiko bersalin di paraji, untuk masalah biaya bisa menabung dari sekarang karena kehamilannya masih muda masih ada waktu untuk mengumpulkannya, dan mengajak responden untuk membawa istrinya bersalin di tenaga kesehatan karena istrinya termasuk salah satu resiko tinggi, akhirnya responden pun mengerti dan mau membawa istrinya untuk bersalin di tenaga kesehatan.

Salah satu prinsip dasar asuhan sayang ibu adalah dengan mengikutsertakan suami dan keluarga selama proses persalinan dan kelahiran bayi. Berdasarkan data yang diperoleh dari hasil penelitian bahwa sebanyak 62 orang $(71,2 \%)$ Suami sudah merencanakan akan mendampingi istrinya ketika bersalin, dan sebanyak 61 orang $(70,1 \%)$ akan meluangkan waktu untuk mengantar istrinya bersalin, disini suami mempunyai peran memberi dukungan kepada istrinya dalam menghadapi proses persalinan, agar persalinannya berjalan dengan baik, tapi ada sebagian suami yang tidak bisa mendampingi istrinya pada saat bersalin dengan alasan tugas yang tidak bias ditinggalkan, sehingga suami meminta orang tua istrinya untuk menemani saat persalinan nanti, dan ada juga suami yang ingin sekali menemani istrinya saat persalinan nanti tapi ia mempunyai kelemahan saat melihat darah tidak kuat dan merasa lemas, pendamping persalinan bukan hanya oleh suami tapi bisa oleh siapa saja asalkan ibu merasa nyaman dan tenang pada saat persalinan. 
banyak hasil penelitian menunjukan bahwa jika para ibu diperhatikan dan diberi dukungan selama persalinan dan kelahiran bayi serta mengetahui dengan baik mengenai proses persalinan dan asuhan yang akan mereka terima mereka akan mendapatkan rasa aman dan keluaran yang lebih baik (Enkin, 2002).

Selain memilih penolong persalinan tempat bersalin pun merupakan salah satu yang penting dalam persiapan persalinan, berdasarkan data hasil penelitian sebanyak 52 orang $(59,8 \%)$ suami sudah memilih tempat untuk persalinan istrinya yang disesuaikan dengan keterjangkauan baik secara ekonomi maupun jarak tempuh. Hal ini sesuai dengan Wardoyo (2007)

Tempat melahirkan hendaknya disesuaikan dengan jarak tempuh dari rumah untuk memperkirakan waktu sampai ke tempat, prosedur masuk, fasilitas yang ada, biaya persalinan dan lokasi kamar bersalin agar dalam keadaan darurat mempercepat samapai ke tempat tujuan.

Berdasarkan rekapitulasi jawaban responden dapat diketahui bahwa dukungan suami dalam persiapan persalinan pada ibu hamil di Desa Simpen Kidul Kecamatan Limbangan Kabupaten Garut tahun 2012 diperoleh bahwa sebesar $54 \%$ mendukung dalam persiapan persalinan, hal ini disebabkan karena dalam mempersiapkan persalinan bukan hanya tanggung jawab istri saja tetapi juga peran suami sangat mendukung terhadap persiapan persalinan. Dengan adanya dukungan suami dalam mempersiapkan persalinan akan meringankan beban istri, selain itu juga akan memberikan ketenangan dan kenyamanan kepada istri selama menunggu proses persalinan. Dukungan suami yang paling banyak diberikan dalam bentuk persiapan biaya yaitu sebanyak 70 responden $(80,5 \%) \quad$ sudah mempersiapkan biaya untuk persalinan.

\section{Persiapan Persalinan}

Berdasarkan hasil penelitian mengenai persiapan persalinan pada ibu hamil di Desa Simpen Kidul Kecamatan Limbangan Kabupaten Garut tahun 2012, diperoleh bahwa ibu hamil melakukan persiapan persalinan ada pada kategori kurang sebanyak 57 responden $(65,5 \%)$, walaupun begitu tapi sebagian responden sudah melakukan persiapan persalinan diantaranya sebanyak 59 orang $(67,8 \%)$ sudah memilih tempat persalinan yang akan digunakan, 58 orang $(66,7 \%)$ responden memilih petugas kesehatan untuk membantu pada saat persalinan,dan 50 orang $(57,5 \%)$ sudah mempersiapkan biaya untuk persalinan dan sebanyak 50 orang $(57,5 \%)$ sudah memilih pendamping saat persalinan. Responden mengatakan Persiapan persalinan sangat penting dilakukan tapi kebanyakan responden belum sepenuhnya mempersiapkan persalinan walaupun suaminya sudah memberikan dukungan tapi masih tetap ada istri yang tidak mempersiapkan persalinan, sebagian responden mengatakan ada yang belum mengetahui golongan darah sehingga ia tidak bisa mempersiapkan pendonor untuk persalinannya, peneliti menganjurkan ibu untuk memeriksakan ke puskesmas, bukan masalah biaya yang dipikirkan tapi ibu takut dengan jarum suntik menurut responden diperiksa golongan darah dengan jarum besar sehingga ibu takut untuk memeriksakan, disini peneliti memberikan penjelasan kepada ibu tentang teknik pemeriksaan golongan darah dan menganjurkan kepada ibu untuk memeriksakan $\mathrm{HB}$, sehingga ia bisa mempersiapkan pendonor darah untuk persalinannya nanti. Beragam 
persiapan yang belum dilakukan oleh ibu tapi tetap ada sebagian persiapan yang telah dilakukan oleh ibu hal ini sesuai dengan teori yang menyatakan Sebagian besar ibu sudah melakukan persiapan persalinan karena Persiapan persalinan merupakan bagian terpenting dari proses persalinan yang ditujukan untuk meningkatkan kesehatan optimal menjelang persalinan dan segera dapat memberikan laktasi. Persiapan persalinan adalah segala sesuatu yang berhubungan dengan tindakan seseorang dalam mempersiapkan dan menyongsong kelahiran seorang bayi (Senduk, 2007). Persiapan persalinan adalah persiapan yang dilakukan secara bersama oleh seluruh keluarga, masyarakat, tenaga kesehatan, penyedia fasilitas kesehatan dan pemerintah dalam menghadapi persalinan dan

\section{F. Simpulan dan Saran}

Berdasarkan hasil penelitian dan pembahasan yang telah diuraikan pada bab sebelumnya, maka dapat disimpulkan sebagai berikut :

1. Dukungan suami dalam persiapan persalinan pada ibu hamil di Desa Simpen Kidul Kecamatan Limbangan Kabupaten Garut Tahun 2012 ada pada kategori mendukung.

2. Persiapan persalinan ibu hamil di Desa Simpen Kidup Kecamatan Limbangan Kabupaten Garut tahun 2012 ada pada kategori kurang.

\section{Saran}

1. Bagi Ibu

Ibu hamil harus lebih meningkatkan pengetahuan dalam persiapan persalinannya dengan mengikuti kegiatan kelas hamil yang di adakan oleh bidan desa setempat supaya persiapan persalinannya lebih baik.

2. Bagi Suami

Suami harus memberikan dukungan dalam persiapan persalinan kepada istrinya dan membantu istri mempersiapkan persalinan. kemungkinan komplikasi pada persalinan. Pelaksanaan Persiapan persalinan dapat dipengaruhi oleh pengetahuan, sosial, ekonomi dan lingkungan sekitarnya yang mendukung. (Hartono, 2007). Dalam mempersiapkan persalinan dapat melibatkan ibu hamil, suami serta keluarganya terutama pada trimester III untuk memastikan bahwa persiapan persalinan yang bersih dan aman serta suasana yang menyenangkan akan direncanakan dengan baik (Wijono W, 2006).

Berdasarkan rekapitulasi jawaban responden dalam mempersiapkan persalinan ada pada kategori kurang yaitu sebesar 65,5 \%, hal ini disebabkan karena masih ada bahkan banyak hal-hal yang belum disiapkan oleh responden.

\section{Bagi Puskesmas}

Petugas kesehatan khususnya petugas yang berada di Wilayah Kerja Puskesmas Limbangan Kecamatan Limbangan Kabupaten Garut harus berusaha meningkatkan kinerja pelayanan kesehatan khususnya mengenai persiapan persalinan dengan cara memberikan pelatihan kepada bidan desa seperti pelatihan APN.

4. Bagi Bidan Desa

Disarankan untuk mengadakan kelas hamil di desa setempat untuk semua ibu hamil. 


\section{G. Referensi}

Depkes

RI.(2004). Pelayanan Antenatal. Availabel from URL :http://www depkes.go.id. Diakses tahun 2012.

Depkes RI, (2008). Asuhan Persalinan Normal. Penerbit JNPK-KR Jakarta. KBBI,(2005).

Dukungan Suami. Availabel fromURL:http://www.duniapsikolo gi.com. Diakses tahun 2012.

http://www.pentingnyasuami.com.

Diakses tahun 2012.

Manuaba, Ida Bagus Gde. (1998). Ilmu Kebidanan, Penyakit Kandungan dan Keluarga Berencana Untuk Pendidikan Bidan. Penerbit Arcan. Jakarta. http://ekanurmawaty.blogspot.com. Diakses tahun 2012.

Notoatmodjo, (2002) Metodologi
Penelitian kesehatan, edisi revisi: Penerbit Rineka Cipta. Jakarta.

Notoatmodjo, (2010) Metodologi Penelitian Kesehatan, edisi revisi: Penerbit Rineka Cipta. Jakarta.

Notoatmodjo. (2007). Kesehatan masyarakat: Teori dan Motivasi. Rhineka Cipta. Jakarta.

Prawirohardjo, (2002). Buku Panduan praktis Pelayanan Kesehatan Maternal dan Neonatal. Penerbit YBP Sarwono Prawirohardjo bekerja sama dengan JPNPKKR - POGI JHPIEGO/MNH PROGRAM. Jakarta.

Saifuddin, (2002). Pelayanan Kesehatan maternal dan Neonatal. Penerbit Yayasan

Bina Pustaka Sarwono Prawirahadjo. Jakarta. 